\title{
An Economist with Attitude on Steroids: Remembering Gordon Tullock
}

\author{
David Colander \\ Middlebury College, Middlebury, Vermont 05753.
}

Eastern Economic Journal (2015) 41, 295-297. doi:10.1057/eej.2015.32

Most people saw Gordon and me as opposites. I was the opposition. ${ }^{1}$ I was an out-of-sync economist with leftish leanings, whereas Gordon was the out-of-sync economist with rightish leanings. Actually, right and left are far too one-dimensional to capture political leanings and our political views were much closer than it seemed on the surface; both of us were in the Classical liberal tradition, with me leaning a bit more toward Mill and Gordon leaning a bit more toward Hayek. But the fact that we were both out of sync created a bond between us that papered over the few differences in normative views that we might have had in terms of politics.

Where we were in sync was in terms of temperament toward the establishment. We both saw it as something best treated as a fire hydrant to piss on, not as something to be treated with blind respect. He was far more skilled and successful at wetting hydrants than I. In fact he was so successful that for me, he was an alternative establishment, which meant that he had numerous students and followers who considered him above question. I suspect Gordon enjoyed that fact that I did not consider him above question; establishments need constant wetting to keep them honest.

The advantage of such an out-of-sync temperament is that it allows one to question ideas and views that are unthinkingly accepted, and which push the analysis as far as it can be pushed, and often a little bit further. This often leads to seemingly absurd conclusions, which upon reflection sometimes become not so absurd — what becomes absurd is the unquestioned acceptance of existing reality. Gordon would point out multitude of absurdities in economic thinking, and in doing so he made enormous contributions to economics.

I never learned about Gordon in my classes. When I studied economics in the late 1960s and early 1970s he was one of those strange public choice people whose work was not covered in establishment public finance classes. Luckily, for me, his work did get a mention in Carl Shoup's public finance class. He told us that there were some economists down in Virginia with strange views. That mention led me to Gordon's writings, which are probably best described as "economics with attitude on steroids." Thereafter I followed Gordon's works carefully. When I first read his work, one of the early articles was one entitled "The Charity of the Uncharitable." It bothered me so much that I wrote a response, pointing out the jumps in logic and the many implicit value judgments hidden in it.

I submitted the paper and it was rejected. I remember that one reviewer said that he suggested rejecting it because, while I was right in all my points, I was not saying anything 
that good economists did not know, and that one had to make special allowances for Gordon, because embedded in his rants were often gems that made his work worth publishing and reading.

At the time, that justification for rejection infuriated me - how could a journal publish articles with implicit values and faulty logic in them, and then not be willing to publish a response pointing out the problems? But, over time, I learned that most published articles had implicit values and faulty logic in them if one dug deeply enough. Gordon's stood out because he embedded slightly different values than did the majority of the profession, and he delighted in pointing out the absurdity of many of the standard views.

I eventually came to understand that the reviewer who rejected my paper was right about Gordon, but wrong about rejecting my paper. Taking an alternative perspective, as Gordon did, and being willing to push it even when it challenged conventional thinking, is what leads to a deepening of our understanding; it is what moves the field ahead. That's why Gordon's contributions to public choice theory and rent seeking are enormous and will continue to play important roles in economic thinking for decades to come. But presentations of alternative perspectives only change thinking if they lead to dialog and interchange. People must react to the provocation, not simply avoid it. My rejected paper may have been not worth publishing, but at least it engaged Gordon's idea. By rejecting it, the editors followed the establishment path of disengagement, which is a putdown of not only my work, but also of Gordon's. His work is not as influential as it should have been, because the profession far too often simply refused to engage it.

My work engaged it, and my criticisms of Gordon should be seen as a tribute to him, and the importance of his ideas. My basic criticism of his work comes down to a difference in our views of human nature. His modeling assumption was that people are selfish; mine is that people are a blend of selfish and non-selfish motives, and that existing institutions can cause people to express different degrees of selfishness. If I am right, any simple public choice argument based on an assumption of narrow self-interested voting must be given up; the fact that people vote, even when the probability of that vote making a difference is miniscule, undermines it. Similarly, with rent-seeking. Distinguishing rent seeking from profit seeking when people have both social and selfish motives has no easy answer. Any policy conclusion involves numerous normative and institutional judgments that undermine any simple application of the idea to policy.

In my view, Gordon did not give these limitations of his model sufficient focus. I made this latter point in my rather acerbic review of a book that Gordon co-edited, The Political Economy of Rent Seeking. The invitation to write the review had come from Gordon, who was one of the editors of both the book and the journal. I was not kind. I think I described the book as a couple of gems on a bed of Slim Jims, and suggested that the editors had decided to draw some rents rather than do the harsh editing that was needed to increase the gem to Slim Jim ratio. He published my review, but wrote me that in it I was lese majeste, which indeed it was. I wrote him back that I took his comment as a complement, and that I had learned the style from him.

Over the years I interacted in person with Gordon a number of times. The first time I spent much time with him was down in Miami when he visited the Law and Economics Center and I was teaching at the university. While there, we soon struck up a conversation and a friendship. It also almost killed me, or at least scared me to death — it was there that I learned that one did not accept a ride with Gordon if one valued one's life. He treated stop signs and traffic signals as he treated the establishment, which meant with no respect.

Thereafter we would often get together for dinner or lunch when we were at a conference together. During these meetings we would argue about whatever subject that came up - Gordon always had a position, and it was always interesting. I remember 
one conference in New York where we decided to visit the Metropolitan Museum together. The Museum had a "voluntary admission" charge - I think it was US $\$ 5.00$ back then which Gordon considered absurd. So when we entered, he pulled out a penny, and gave it to the attendant. I was totally embarrassed, which was Gordon's goal in doing that, and when I went through I surreptitiously donated $\$ 10$ to assuage my social guilt. I did not tell Gordon because he would have (correctly) pointed out the many contradictions in my social charitable habits had he known.

Another time, I was on a panel at the Southern Economic Association Meetings honoring Gordon. I was the token lefty there. In my remarks, I emphasized Gordon's social nature and the behind the scenes help he provided for his students. Here is just one example: when he discovered that his students could not get their work published in traditional journals, he put up the money to start Public Choice to provide them with an outlet. I contrasted Gordon's actions with the way in which a well-known leftish professor had treated his graduate students at a program that had socialist leanings. I argued that, the Metropolitan Museum aside, Gordon had stronger social tendencies than most economists, but that he did his best to hide them.

The last time I saw Gordon was at George Mason, where I was debating David Levy on whether socialism or capitalism was the best system. My job was to defend capitalism; David's was to defend socialism. I used a variation of the Millian defense of markets, arguing that the system we have in the United States is socialism (such an argument plays well at George Mason), and in defending capitalism I defended it as a system that can be, not as the system we have. As Mill argued "if as much pains as has been taken to aggravate the inequality of chances arising from the natural working of the principle had been taken to temper that inequality by every means not subversive of the principle itself; if the tendency of legislation had been to favor the diffusion, instead of the concentration of wealth - to encourage the subdivision of the large masses, instead of striving to keep them together - the principle of individual property would have been found to have no necessary connection with the physical and social evils which almost all Socialist writers assume to be inseparable from it." Gordon approved of my defense, and we parted agreeing for once to agree with each other, as down deep, we did on so many issues.

\section{Note}

1. Gordon Tullock died November 3, 2014. This remembrance was written for his memorial service held in April 2015. 